\title{
The Importance of Sea Boat as a Supporting Transportation Facility for People and Goods
}

\author{
Elfrida R Gultom $^{1 *}$ \\ ${ }^{1}$ Faculty of Law, University of Trisakti, Jakarta, Indonesia
}

\begin{abstract}
KM. Sinar Bangun which sank in Lake Toba on June 18, 2018 caused 4 passengers died and 183 others missing. Four days later, the accident occurred again on the same lake, involved KM. Ramos Risna Marisi. The results of the investigation stated that this accident happens since the ship did not meet the seaworthy criteria and not feasible for sailing. Many cases about ship accidents are caused by other factors. Then, how are the rules regarding seaworthiness and ship loading according to the Regulation on Sea Transportation? Moreover, what are the efforts of the Government, Ship and Transport Owners to minimize accidents at sea? These are going to be the subject matter of this research. The research method used is Normative method, it is done by analyze the data descriptively, using secondary data which are obtained through literature study. The conclusion of this research is that the seaworthiness according to shipping regulations is the condition of the ship that must meet the requirements of ship safety, prevention of marine pollution from ships; Escort, Loading, Health and welfare of crew and passengers and legal status for sailing in certain waters. Efforts made by the Government and the responsibility of the Ship and Carrier Owner are to impose strict regulations on the obligation of the Sea Freight Company to check the feasibility of the sea of ships before sailing for carrying people and goods
\end{abstract}

\section{Introduction and literature review}

The results of NTSC investigations around 2010-2016, stated that the total number of ship accidents in Indonesia was 54 cases[1], while the percentage of the accidents from various consequences of the period 2010-2016 described as follows; burn or explode 35\%, collision $31 \%$, sink $24 \%$, content $6 \%$ and other causes $4 \%$ [1]. Based on the report of the National Committee in 2017, the sea accidents in Indonesia reach $34 \%$. These accidents increased almost twice compared to 2016, which were 18 accidents. Most accidents were caused by ships exploding or burning, namely 14 accidents. While others, 6 cases of drowning, 6 cases of collision ships, 6 cases of ship ran aground, and 2 other accidents [2]. Thus, many factors are the cause of accidents at sea, and all of them are closely related to the prudence and thoroughness of the executor of duties and authority in the field, whether the Government as the executor checking the administration of the ship when it will sail is also the responsibility of the ship owner to maintain and submit to the rules that apply in carrying out transportation

* Corresponding author: elfrida.r.goeltom@gmail.com 
activities of people and goods through the sea, among others, pay attention to the requirements that must be adhered to in activities by sea, namely the ship must be in a seaworthy and screen-worthy condition. Ship feasibility is closely related to shipping safety and its implementation must be assisted by the means of shipping safety because of the risk of ship accidents is very high [3]. Describe about the rules related to the ship and seaworthiness based on the regulations regarding to the sea transportation in Indonesia and the efforts made by the Government, Ship and Transport Owners to minimize accidents at the sea, are the objectives of this research. Based on this background, the Author will discuss the importance of sea boat as a means to support the transportation for people and goods.

\subsection{Seaworthy and screen-savvy}

Article 1 Number 33 of the Law of the Republic of Indonesia Number 17 of 2008 concerning shipping, explains "Ship feasibility is a condition of a ship that meets the requirements of ship safety, prevention of pollution from the ship, guarding, making, health and welfare of the crew and passengers and the legal status of the ship to sailing in certain waters" [4]. The International Safety Management Code or ISM Code also states that the safety of shipping must at least meet two criteria, namely seaworthy and screen worthiness. A ship is said to be sea worth if the requirements of the materials, construction, buildings, machinery and electronics are fulfilled, all of which are proven by an original certificate. The International Safety Management Code is an international standard of safety management in the operation of ships and prevention / control of environmental pollution. In accordance with the awareness of the importance of human factors and the need to improve the operational management of ships in preventing ship, human, cargo / property and property accidents as well as preventing pollution of the marine environment, the IMO issued regulations on ship safety management and protection of the marine environment known as International Safety Management Regulations (ISM Code) which are also consolidated in SOLAS Convention [5].

When preparing a voyage, it is necessary to know the instructions on how to act when a ship accident happen, due to collisions, aground, sinking, fires, bumps and major force or natural accidents. Ship maintenance procedures, among others: (a) the time has come for the ship to dock, (b) annual maintenance, (c) emergency care, (d) quarterly maintenance. In addition, it is necessary to intervene, shipping associations to help each other, improve safety and prevent ship accidents to a minimum. In order to implement all policies in the field of safety, the Company must have a Safety Management System (Safety Management System) in which, it is a facility for all personnel both on land and in the sea. The company builds this system by following guidelines and examples from the documents provided by the International Safety Management Code (ISM code.)[5].

The feasibility of the ship is very closely related to shipping safety. When the ship's seaworthiness is not assisted by the means of shipping safety, the risk of ship accidents is very high. Elements related to shipping safety in accordance with Law Number 17 of 2008 are as follows: Shipping, Ship, Waters, Port, Cruise line, Means of navigation, navigation aids, Telecommunications and underwater works of ships carried out under water that are special in nature.

Seaworthy means that the ship is worth to travel or sail by sea, while Cargo-worthy means the ship is worth of receiving the cargo where the ship's equipment is in accordance with the properties of the item being loaded. Thus, before and the beginning of a voyage, the captain must make sure that the ship is seaworthy, prepare the ship, completing the ship's equipment and the needs of the ship. (Properly Manned) Making the room facilities of the ship to fit the load (good load), both when loading, storing, dismantling the goods. If the conditions above have been fulfilled, then the vessel is awarded a Certificate of Seaworthiness, it is a permit 
to sail from a port issued by Syahbandar which states that the ship has been seaworthy to sail because it has met the technical requirements [6].

\subsection{Ship}

Ship is a mode of sea transportation which is needed to load or dismantle various kinds of economic goods from the North to the East in all over the ports in Indonesia. This activity is needed to develop and prosper the provinces, cities, sub-districts and remote areas [7]. The definition of a ship in Article 1 Number 36 is a water vehicle from any kind and driven by mechanical power, wind power, and including vehicles with dynamic bearing capacity, underwater vehicles and floating equipment and floating buildings that are not move around [7].

\subsection{Responsibilities of the Government and the Company for Ship Safety in transporting people and goods}

Law No. 17 of 2008 regulates the responsibilities of each party in shipping, especially when an accident occurs. The skipper and ship owner is threatened with a number of criminal offenses when an accident happens. Government and stakeholder needs to improving transportation modes in order to minimize the potential for recurrence of ship accidents. Some of the results of accident investigations show that human error is often being the cause of the accident. However, it does not mean that the fault is solely aimed at the crew. There is a part of the other aspects which are apart from the capabilities of the crew and skipper, for example; the condition of the ship's health, weather conditions, negligence of government officials at the port, and there may be other factors that are interrelated and have an impact until finally an accident occurs[8].

Law No. 17 of 2008 concerning on shipping. It regulates the safety aspects of shipping very well, and also the responsibilities of each party, both those directly and indirectly related, are given a portion of their respective responsibilities, as well as strict rules that impose sanctions both administratively and criminal against parties who are proven to have violated the required matters[8].

\section{Objective of the study}

The object of research is about the safety of ships in sailing. Two important conditions that must be fulfilled by a ship in carrying out its duties for carrying passengers and cargo are seaworthy and screen worthy.

\section{Methodology}

The research method used is Normative which is analyzed descriptively, using secondary data obtained through literature study. It is done by reading and studying various written sources that are related to the issues discussed.

\section{Discussion}

The number of the ship accident cases is become one of the signs of the importance to make system improvements in the sea transportation. Ship accidents occur with a variety of causes such as sinking, rolling, aground and collision. The results of the NTSC investigation found 
some conclusions related to the contributing factors; including human error, technical errors and the weather [9].

\subsection{Natural factors (force majeure)}

Greatly contribute to a ship accident. Bad weather factor mostly causes ship accidents. Based on data from the Shipping Court in 2011-2015, the total number of ship accidents due to natural factors was 86 times [10]. When it is linked to the seaworthy criteria contained in the ISM Code, the cause of weather accidents is due to unpreparedness in dealing with emergencies. Bad weather is a natural factor but accidents that are caused by bad weather can be anticipated when the preparedness in dealing with emergencies is well done. In this case, also requires the company or ship owner to be able to identify potential emergencies that occur on board and the procedures that must be performed to anticipate the situation.

\subsection{Technical factors}

These factors are quite diverse and more technical - can be said to be other factors. Related to accidents caused by these other factors, based on data from the Shipping Court in 20112015 there were 23 accidents with various causes [10]. However, in general it can be concluded that accidents caused by other factors are due to non-compliance with the seaworthy clause in the ISM Code which is related to the operation of the vessel. The company or ship owner should have made procedures, plans and instructions, including matters as the main concern in ship operation related to the safety of the crew, the ship itself and maritime protection.

\subsection{Human error factor (human error)}

Based on data from the Shipping Court in 2011-2015, the total number of ship accidents due to human factors is 47 times [10]. It can be concluded that the company / ship owner does not comply with the seaworthy clause in the ISM Code related to resources and labor. The placement of these resources and workforce with respect to qualifications that are in accordance with what is needed, experience, can run the company's operating standards well, as well as effective communication can be built in emergency situations.

The vessel must meet safety standards and the requirements for a vessel declared to be sailing feasible before sailing, i.e. checking all documents related to the passenger manifest, passing physical checks, having safety equipment, as well as ensuring the number of passengers does not exceed the capacity [11]. The seaworthiness of a ship must comply with the provisions contained in the International Safety Management (ISM) Code chapter IX issued by IMO in the 2014 edition and declared screen worthy if the safety of the sailing vessel consists of some criteria, including; the condition of the ship and the crew qualification to maintain ship safety. These two criteria indicate that the safety of the ship becomes the scope of responsibility to the land side, while, the port and safety on board are the responsibility of the captain on board.

According to Law Number 17 of 2008 related to Shipping, in Chapter I in which it is concerning in General Provisions Article 1 Paragraph 1 states that Shipping is a unified system consisting of transportation in water, seaport, safety and security, as well as maritime environmental protection. Paragraph 32 states that Sailing Safety and Security is a condition of fulfilling the requirements concerning in the water transportation, ports and the maritime environment. In Paragraph 33, it is stated that the ship's feasibility is the condition of the ship that meets the requirements of ship safety, prevention of water pollution from ships, guarding, 
load lines, loading, welfare of the ship's crew and passenger health, vessel legal status, safety management, and management security of the ships to sail in certain waters.

Paragraph 34 states that ship safety is the condition of a ship that meets the requirements of material, construction, building, machinery and electricity, stability, arrangement and equipment including auxiliary equipment and radio, ship electronics, as evidenced by a certificate after inspection and testing. In Paragraph 41, the captain of the ship is one of the Ship Crew who is the highest leader on the ship and has certain powers and responsibilities in accordance with the provisions of the legislation.

Paragraph 56 states that Syahbandar is a official government at the port appointed by the Minister and has the highest authority to carry out and supervise the fulfillment of the provisions of legislation to ensure the safety and security of shipping. International Shipping Safety is listed in the 1974 SOLAS Safety Article IX, namely International Safety Management (ISM). The code amended by the 1978 Amendment applies to all ships shipping between ports in the world [5]. One of the things that need to be considered in shipping safety is scouting of ships. Boat guidance starts when the ship will enter or exit the port pool. Pandu is divided into sea guides and city guides. Sea guides can be placed on top of a commercial ship that sails to the destination port. The airport guide carries out the task is only limited to the work environment or the port pool, so the airport guide does not guide ships that sail between ports but only in the port water area [12].

\section{Conclusion}

Based on the three factors that causing ship accidents above, a conclusion is obtained that in carrying out passenger and cargo activities, the ship must fulfill the safety principles that have been emphasized in the applicable regulations in Indonesia and must be obeyed, based on Law No. 17 of 2008 and the International Safety Management Code in Chapter IX of SOLAS which contains provisions on International Management for safe operation of ships and prevention of pollution. The operation of the ship must be carried out by the parties responsible for shipping safety. This is to reduce the potential for ship accidents. The company or the ship owner must be responsible for the ship that will sail; i.e. must have passed the sailing safety completeness test.

\section{References}

1. Chairperson of the Sub-Department of the Shipping Accident Investigation Committee, Shipping Accident in 2010-2016 (Media Release of the 2016 NTSC, 25 November 2016)

2. D.Br Matondang, Naik 2 Kali Lipat, KNKT Catat Ada 34 Kecelakaan Pelayaran di 2017 (Detik.com 2017) https://news.detik.com/berita/d-3821137/naik-2-kali-lipat-knktcatat-ada-34-kecelakaan-pelayaran-di-2017

3. R.Y.C. Aguw, Administratum, 1, 1, Pp. 45-56 (2013)

4. Law No. 17 Year 2008

5. ISM Code was born from the need for ship safety management caused by high rates of workplace accidents in the maritime and shipping world. Based on the IMO resolution A.741 (18) which was ratified on November 4, 1993 was born the International Management Code for the Safe Operation and for Pollution Prevention. This code or provision is then adopted by SOLAS (Safety of Life At Sea) in one chapter, namely in chapter IX. SOLAS is one of the international conventions for safety in the maritime world. In this Chapter IX of SOLAS, the ISM Code is explained as a Provision of 
International Management for safe operation of ships and prevention of pollution adopted by the Organization with resolution A.741.

6. A. Budi, Pengertian Laik Laut dan Laik Muat (akademiasuransi, 16 Oktober 2012 ) http://www.akademiasuransi.org/2012/10/pengertian-laik-laut-dan-laik-muat.html Accessed on August, 10th 2018

7. HM. Thamrin, Jurnal Ilmiah Widya 3, 2, Pp.110 (2015)

8. [RI Ministry of Transportation] Ministry of Transportation of the Republic of Indonesia. 2008. Law Number 17 of 2008 concerning shipping. Jakarta (ID): RI Ministry of Transportation.

9. S. Hasugian, A.A. I. S. Wahyuni , M. Rahmawati, Arleiny, Warlit 29, 2, Pp. 229-240 (2017)

10. [Mahpel RI] Shipping Court of the Republic of Indonesia. 2017. 2011-2015 vessel accident data. Jakarta (ID): RI Ministry of Transportation.

11. H. Rahman, A. Satria, B. H. Iskandar, D. A. Soeboer, pspalbacore 1, 3, Pp. 277-284(2017)

12. DA. Lasse, Keselamatan Pelayaran di Lingkungan Teritorial Pelabuhan dan Pemanduan Kapal. (Grafindo Persada, Jakarta, 2014) 